\title{
Insulin-like growth factor-binding protein-1 in umbilical artery and vein of term fetuses with signs suggestive of distress during labor
}

\author{
J Verhaeghe, J Billen ${ }^{1}$ and L C Giudice ${ }^{2}$ \\ Department of Obstetrics and Gynaecology, and Laboratorium voor Experimentele Geneeskunde en Endocrinologie, Katholieke Universiteit Leuven, Leuven, \\ Belgium \\ ${ }^{1}$ Department of Laboratory Medicine, Katholieke Universiteit Leuven, Leuven, Belgium \\ ${ }^{2}$ Department of Gynecology and Obstetrics, Stanford University Medical Center, Stanford, California, USA \\ (Requests for offprints should be addressed to J Verhaeghe, Department of Obstetrics and Gynaecology, U.Z. Gasthuisberg, Herestraat 49, 3000 Leuven, \\ Belgium; Email: johan.verhaeghe@uz.kuleuven.ac.be)
}

\begin{abstract}
Insulin-like growth factor-binding protein-1 (IGFBP-1) is believed to be an inhibitory factor for fetal growth. The regulation of IGFBP-1 secretion in the fetus is uncertain, although insulin and oxygen tension $\left(\mathrm{PO}_{2}\right)$ and saturation are thought to play a role. We studied IGFBP-1 levels in umbilical cord artery (UA) and vein (UV) of 98 singleton fetuses at term with clinical signs of distress during labor, i.e. meconium-stained liquor or/and an abnormal fetal heart rate tracing. Blood gas values and serum C-peptide and IGFBP-1 concentrations were measured in both UA and UV. Twenty-five fetuses had an UA $\mathrm{pH}<7 \cdot 20$. The concentrations of IGFBP-1 were similar in UA and UV and were highly correlated $(r=0 \cdot 98)$. IGFBP-1 levels were inversely correlated with birth weight, with increased concentrations in small-for-gestational age fetuses $(\leq 10$ th weight percentile). IGFBP-1 levels were negatively correlated with C-peptide concentrations, and remained so after correction for birth weight $(r=-0 \cdot 37$ for both UA
\end{abstract}

and UV; $P<0 \cdot 001)$; more specifically, IGFBP-1 levels were increased in the lowest $\mathrm{C}$-peptide quartile $(<0.23 \mathrm{nmol} / \mathrm{l})$ compared with the other quartiles. In addition, IGFBP-1 levels were inversely correlated with $\mathrm{PO}_{2}$ values $(r=-0.39$ in $\mathrm{UA}$ and $r=-0.34$ in $\mathrm{UV}$; $P<0 \cdot 001$ ); quartiles of $\mathrm{UA}$ and $\mathrm{UV} \mathrm{PO}_{2}$ showed a gradual increase in IGFBP-1 concentrations with lower $\mathrm{PO}_{2}$ values. A regression model with $\mathrm{C}$-peptide and $\mathrm{PO}_{2}$ values as independent variables predicted IGFBP-1 concentrations $\left(R^{2}\right.$ of model was $0 \cdot 25$ and 0.22 for UA and UV respectively; $P<0 \cdot 001)$. Other blood gas values $(\mathrm{pH}$, $\mathrm{PCO}_{2}, \mathrm{HCO}_{3}{ }^{-}$and base deficit) did not correlate with IGFBP-1 levels. The data of this study indicate that serum IGFBP-1 levels in term fetuses are determined by both insulin and $\mathrm{PO}_{2}$ levels, and suggest that acute hypoxemia stimulates IGFBP-1 secretion in the fetus.

Journal of Endocrinology (2001) 170, 585-590

\section{Introduction}

There is suggestive evidence that insulin-like growth factor (IGF)-binding protein-1 (IGFBP-1), one of the six IGF-binding proteins that bind the IGF ligands (IGF-I and IGF-II), is an inhibitory factor for fetal growth. In the fetus, the IGFBP-1 gene is mainly expressed in the liver (Han et al. 1996). IGFBP-1 levels have been documented to be increased in mixed umbilical cord (UC) serum or in umbilical artery (UA) and vein (UV) serum of small-forgestational age (SGA, <10th birth weight percentile) fetuses or fetuses with clinically recognized intra-uterine growth retardation (IUGR) (Wang et al. 1991, Verhaeghe et al. 1993, Giudice et al. 1995, Osorio et al. 1996, Cianfarani et al. 1998b). Similar results were obtained with fetal serum sampled in utero by cordocentesis (Langford et al. 1994, Östlund et al. 1997). In a small group of twins discordant for birth weight, UC serum IGFBP-1 levels were markedly higher in the growth-retarded members (Verhaeghe et al. 1996). Serum IGFBP-1 concentrations were found to be negatively correlated with total and free IGF-I concentrations in normal fetuses at birth (Klauwer et al. 1997) and in IUGR fetuses in utero (Östlund et al. 1997) and at birth (Osorio et al. 1996, Cianfarani et al. 1998b). IUGR in animal models (rats and sheep) - induced by uterine artery ligation/clamping or maternal fasting - is consistently associated with increased liver IGFBP-1 mRNA abundance (Unterman et al. 1990, Straus et al. 1991, McLellan et al. 1992, Osborn et al. 1992, Price et al. 1992a). Conversely, birth weight was found to be reduced in some strains of transgenic mice that overexpress the IGFBP-1 gene (Rajkumar et al. 1995). Finally, the in vivo administration of IGFBP-1 abrogated the stimulatory effect of IGF-I on body growth in postnatal pituitary-ablated rats (Cox et al. 1994). 
The regulation of IGFBP-1 production in the fetus is uncertain. The stimulatory effect of a drop in utero placental blood flow on fetal hepatic IGFBP-1 gene expression may be mediated, at least in part, by hypoinsulinemia or/and hypoxemia in these fetuses. Indeed, insulin is the major determinant of circulating IGFBP-1 levels after birth in humans and experimental animals, with increased levels in type 1 diabetes but suppressed levels under hyperinsulinemic conditions (reviewed by Lee et al. 1997). In some studies, IUGR in human fetuses (Cianfarani et al. 1998b) and uterine artery ligation in the rat (Unterman et al. 1990) was associated with lower insulin levels. However, we found no difference in UC serum IGFBP-1 levels among two groups of 18 gestational age-matched fetuses with widely different C-peptide levels (Verhaeghe et al. 1993). Regarding fetal oxygenation, UV IGFBP-1 levels were found to be higher in 22 fetuses with an abnormal cardiotocograph tracing during labor than in 19 control fetuses, and there was a negative correlation between the UV pH value and IGFBP-1 levels in the distressed fetuses (Crawford et al. 1995). A chronic reduction in oxygen saturation without uterine artery manipulation in pregnant rats resulted in IUGR and a robust increase in IGFBP-1 mRNA abundance in the fetal liver (Tapanainen et al. 1994). Experiments in sheep showed that the infusion of nitrogen into the maternal trachea acutely raises fetal plasma IGFBP-1 levels, as quantified by ligand and immunoblot analysis (Iwamoto et al. 1992); however, intermittent cord occlusion had no effect on fetal liver IGFBP-1 mRNA abundance (Green et al. 2000).

In the current study, we measured C-peptide and IGFBP-1 levels in the UA and UV of human fetuses with clinical suspicion of hypoxemia during labor. Complete blood gas analysis was carried out in both UA and UV.

\section{Materials and Methods}

We sampled UA and UV blood from 98 term pregnancies (37-42 weeks) at delivery. Multiple pregnancies, and pregnancies with congenital malformations, diabetes mellitus or other medical conditions were excluded. All fetuses were clinically suspected to be hypoxemic in the course of labor either by the presence of meconiumstained liquor $(n=9)$ or the presence of an abnormal electronic fetal heart rate tracing $(n=61)$, or both $(n=28)$. Meconium-stained liquor included any degree of meconium-staining of amniotic fluid (brown or green), detected at spontaneous or artificial rupture of membranes or later in the course of labor. Abnormalities in the fetal heart rate were defined as two or more periods of bradycardia, or repeated late (type 2) or variable decelerations, detected at any time during labor before the delivery process started. Some patients underwent one or more fetal scalp blood gas measurements during labor to guide clinical management. Because of clinical suspicion of fetal distress, delivery was expedited; 25 patients delivered spontaneously, 33 had an instrumental delivery (forceps or vacuum-extraction) and 40 underwent an (semi-)urgent cesarean section. All patients consented orally that blood be sampled from the cord, or consented orally that sampled cord blood could be used for scientific purposes. Blood samples were taken after cleaning the cord with a sterile swab before the placenta was delivered. For blood gas analysis, a heparin-containing syringe was used; for the other measurements, the blood sample was collected into a dry tube. Blood gas analysis was performed within a few minutes on an ABL 700 Analyzer (Brønshøj, Denmark); values for $\mathrm{pH}, \mathrm{PCO}_{2}, \mathrm{PO}_{2}, \mathrm{HCO}_{3}{ }^{-}$and base deficit were recorded. All blood samples were centrifuged within a short interval, and serum was stored at $-20^{\circ} \mathrm{C}$. The series included 42 girls and 56 boys; their birth weight, length and head circumference, as well as gestational age at birth were recorded. The ponderal index (the fetal equivalent of the body mass index) was calculated as birth weight/ $\left(\right.$ length $\left.{ }^{3}\right)$. The percentile $(\mathrm{P})$ of birth weight was classified into categories $\left(\leq \mathrm{P}_{10}, \mathrm{P}_{11-50}, \mathrm{P}_{51-90}\right.$, and $\left.>\mathrm{P}_{90}\right)$ according to recently updated birth weight charts derived from about 429000 births in Flanders, Belgium (Devlieger et al. 2000).

IGFBP-1 was measured with an in-house radioimmunoassay (RIA), using as standard purified IGFBP-1 from amniotic fluid, which was standardized with an enzyme-linked immunoassay from Medix Biochemica (Kauniainen, Finland) that measures total IGFBP-1. The detection limit is $25 \mathrm{pg}$ IGFBP-1 per tube. The withinand between-assay coefficients of variation are $<10 \%$ (Verhaeghe et al. 1999). C-peptide was measured by RIA, as decribed previously (Verhaeghe et al. 1993).

Data analysis was performed with a software program (NCSS, Kaysville, UT, USA).

\section{Results}

UA and UV concentrations of IGFBP-1 and C-peptide were tightly correlated $(r=0.98$ for both parameters; $P<0 \cdot 001)$. There was no difference between IGFBP-1 levels in UA and UV $(n=97 ; P=0 \cdot 76)$, but there was a trend towards lower C-peptide concentrations in UA than in UV in the 96 available UA-UV pairs $(\Delta$ : $0 \cdot 019 \pm 0 \cdot 101 \mathrm{nmol} / 1$ (mean \pm S.D.); $P=0 \cdot 067)$. Mean \pm S.D. (range) values for IGFBP-1 were $112 \pm 128$ (12$1090) \mu \mathrm{g} / \mathrm{l} \quad(3.50 \pm 3.99 \mathrm{nmol} / \mathrm{l})$ in UA $(n=97)$ and $113 \pm 115 \quad(9-878) \mu \mathrm{g} / 1 \quad(3.54 \pm 3.58 \mathrm{nmol} / \mathrm{l})$ in UV $(n=98)$. Because IGFBP-1 and C-peptide data were unequally distributed, the data were log-transformed for further analyses. Each of the histograms of the $\log _{10}$-transformed data was compatible with a Gaussian distribution (data not shown). $\log _{10}$ IGFBP-1 concentrations in both UA and UV were negatively correlated with $\log _{10}$ C-peptide concentrations $(r=-0 \cdot 40$ for both UA and UV; $n=96$ and 97 respectively; $P<0 \cdot 001)$. 
Blood gas analyses showed lower $\mathrm{PO}_{2}(-8 \cdot 4 \pm 6 \cdot 3 \mathrm{~mm}$ $\mathrm{Hg}, \quad$ mean \pm S.D.; $n=94)$ and $\mathrm{pH}(-0.045 \pm 0.064$, $n=98$ ) values in UA than in UV (both $P<0 \cdot 001$ ), but higher $\mathrm{PCO}_{2}(7 \cdot 6 \pm 5 \cdot 6 \mathrm{~mm} \mathrm{Hg}, n=95)$ and $\mathrm{HCO}_{3}{ }^{-}$ $(2 \cdot 9 \pm 18 \cdot 8 \mathrm{mEq} / 1, n=95)$ values (both $P<0 \cdot 001)$. There was a trend for higher base deficit values in UA than in UV $(0 \cdot 16 \pm 0 \cdot 95 \mathrm{mEq} / 1, n=94 ; P=0 \cdot 076)$. Twenty-five fetuses $(26 \%)$ had an UA $\mathrm{pH}<7 \cdot 20,11$ fetuses had an UA $\mathrm{pH}<7 \cdot 10$, and 3 fetuses had an UA $\mathrm{pH}<7 \cdot 00$.

Pearson correlation analysis (row-wise deletion) in 91 UA and 92 UV samples in which all parameters (biometric parameters at birth, blood gas values, and IGFBP-1 and C-peptide measurements) were available, showed that UA $\log _{10}$ IGFBP-1 was negatively correlated with weight at birth $(r=-0 \cdot 20 ; P=0 \cdot 06)$, ponderal index $(r=-0 \cdot 39$; $P<0 \cdot 001)$, UA $\mathrm{PO}_{2}(r=-0 \cdot 39 ; P<0 \cdot 001)$ and $\mathrm{UA} \log _{10}$ C-peptide $(r=-0 \cdot 46 ; P<0 \cdot 001)$. In the UV, $\log _{10}$ IGFBP-1 was negatively correlated with birth weight $(r=-0 \cdot 19 ; \quad P=0 \cdot 07), \quad$ ponderal index $(r=-0 \cdot 39$; $P<0 \cdot 001)$, UV $\mathrm{PO}_{2}(r=-0 \cdot 34 ; P<0 \cdot 001)$, UV $\mathrm{pH}$ $(r=-0 \cdot 20 ; P=0 \cdot 06)$ and $\mathrm{UV} \log _{10}$ C-peptide $(r=-0 \cdot 44$; $P<0 \cdot 001) . \log _{10} \mathrm{C}$-peptide concentrations in UA and UV were positively correlated $(P<0 \cdot 10)$ with weight and length at birth as well as $\mathrm{PO}_{2}$ and $\mathrm{pH}$ values but negatively correlated with $\mathrm{pCO}_{2}$ (data not shown).

The negative correlation between UA and UV IGFBP-1 concentrations and birth weight was further explored by comparing IGFBP-1 levels in four groups of fetuses: SGA $\left(\leq \mathrm{P}_{10}\right)(n=15)$, average-for-gestational age (AGA) between $\mathrm{P}_{11}$ and $\mathrm{P}_{50}(n=39)$, AGA between $\mathrm{P}_{51}$ and $\mathrm{P}_{90} \quad(n=34)$, and large-for-gestational age $\left(>\mathrm{P}_{90}\right)$ $(n=10)$. There was a significant overall difference in UA and UV $\log _{10}$ IGFBP-1 levels (ANOVA for both: $P=0 \cdot 007)$; UA and UV $\log _{10}$ IGFBP-1 levels were increased in the SGA group compared with the other groups (Fig. 1 shows the UA data, UV data not shown). In the subgroup of fetuses with an UA $\mathrm{pH} \geq 7 \cdot 20(n=72)$, $\log _{10}$ IGFBP-1 levels in UA and UV were also higher in SGA fetuses $(n=12)$ than in non-SGA fetuses $(P=0 \cdot 01)$.

Because both IGFBP-1 and C-peptide concentrations in UA and UV were correlated with birth weight, the negative correlation between IGFBP-1 and C-peptide was corrected for weight at birth: after correction, the negative correlation between $\log _{10}$ IGFBP-1 and $\log _{10}$ C-peptide remained highly significant $(r=-0.37$ for both UA and UV; $P<0 \cdot 001)$.

The negative correlation between UA and UV IGFBP-1 and C-peptide was further explored by comparing IGFBP-1 levels in quartiles of $\mathrm{C}$-peptide levels. There was a significant overall difference (ANOVA: $P<0 \cdot 001$ for both UA and UV). The analysis for UA is depicted in Fig. 2 (left panel): $\log _{10}$ IGFBP-1 was significantly higher in the lowest quartile of C-peptide levels compared with the other three quartiles. The results were comparable for UV C-peptide (data not shown).

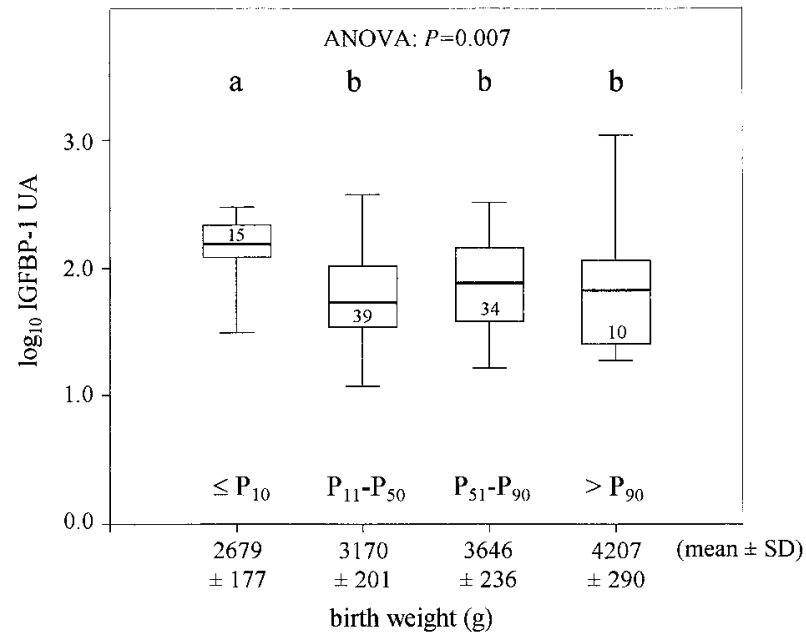

Figure 1 Box-plots of serum concentrations of IGFBP-1 in the umbilical artery in relation to birth weight percentiles: $\leq 10$ th percentile $\left(\leq \mathrm{P}_{10}\right), \mathrm{P}_{11-50}, \mathrm{P}_{51-90}$ and $>\mathrm{P}_{90}$. The number of samples in each group is given in the box. Groups that are significantly different $(P<0 \cdot 05)$ from one another are denoted by a different letter.

The negative correlation between UA and UV IGFBP-1 and $\mathrm{PO}_{2}$ was further explored by comparing IGFBP-1 levels in quartiles of $\mathrm{PO}_{2}$ values. There was a significant overall difference (ANOVA: $P<0 \cdot 001$ for UA, and $P=0.005$ for UV). The analysis for UA is depicted in Fig. 2 (right panel): there was gradual increase in $\log _{10}$ IGFBP-1 levels with lower $\mathrm{PO}_{2}$ values. The results were comparable for $\mathrm{UV} \mathrm{PO}_{2}$ (data not shown).

Because IGFBP-1 was negatively correlated with some blood gas values $\left(\mathrm{PO}_{2}\right.$ and $\left.\mathrm{pH}\right)$ as well as $\mathrm{C}$-peptide levels, we performed multiple regression analyses with $\mathrm{PO}_{2}$ and $\log _{10} \mathrm{C}$-peptide as independent variables for the UA, and $\mathrm{PO}_{2}, \mathrm{pH}$ and C-peptide as independent variables for the UV. In the UV analysis, $\mathrm{pH}$ was not retained as a significant predictor $(P=0.85)$, while $\mathrm{PO}_{2}(P=0.05)$ and $\log _{10}$ C-peptide $(P<0 \cdot 001)$ were significant predictors $\left(\mathrm{R}^{2}\right.$ of model $=0 \cdot 22 ; P<0 \cdot 001)$. Consequently, the final regression model for both UA and UV contained $\mathrm{PO}_{2}$ and $\log _{10}$ C-peptide as independent variables, showing that both variables were significant predictors of $\log _{10}$ IGFBP-1 concentrations (Table 1).

\section{Discussion}

Several observations were made in this study. First, IGFBP-1 concentrations were almost identical in the UA and UV, and all analyses were in essence similar for the UA and UV. It would therefore suffice in further studies to restrict measurements to the UV, which is easier to sample. Similar results were obtained by Wang et al. 


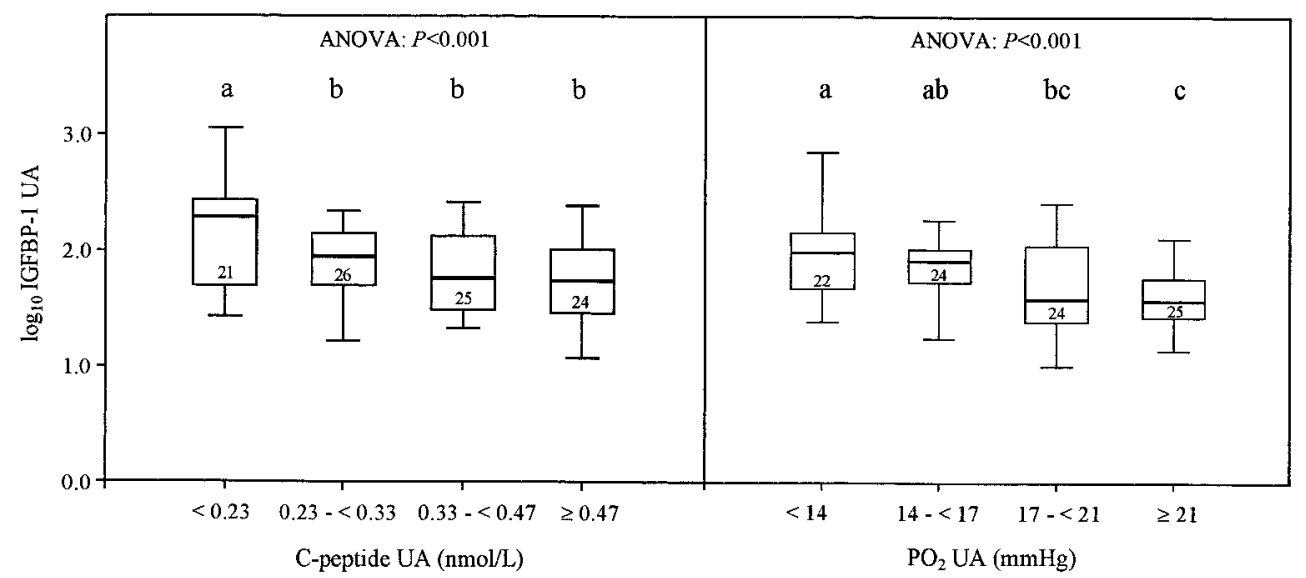

Figure 2 Box-plots of serum concentrations of IGFBP-1 in quartiles of serum concentrations of C-peptide (left panel) and $\mathrm{PO}_{2}$ values (right panel) in the umbilical artery. The number of samples in each group is given in the box. Groups that are significantly different $(P<0 \cdot 05)$ from one another are denoted by a different letter.

(1991), who found a correlation of 0.90 in 56 UA-UV pairs.

Secondly, IGFBP-1 levels in UA and UV were negatively correlated with both insulin (C-peptide) and $\mathrm{PO}_{2}$ levels. The negative correlation with insulin concentrations in fetuses extends numerous studies in postnatal individuals (Lee et al. 1997). The negative correlation with $\mathrm{PO}_{2}$ values is not surprising either, and suggests that acute changes in $\mathrm{PO}_{2}$ in the fetus, prior or during labor, stimulate IGFBP-1 secretion by the liver. In fetal sheep, there is suggestive evidence that acute hypoxemia provokes a rise in IGFBP-1 levels (Iwamoto et al. 1992). Moreover, chronic hypoxemia is a well known stimulatory factor of hepatic IGFBP-1 gene expression in fetal sheep (McLellan et al. 1992) and rats (Tapanainen et al. 1994). Tazuke et al. (1998) showed that IGFBP-1 gene expression is stimulated by hypoxia in HepG2 cells. Three consensus sequences for the hypoxia response elements (HREs) within intron 1 of the IGFBP-1 gene were identified, at least one of which is functionally responsive

Table 1 Multiple regression analysis of serum concentrations of IGFBP-1 (dependent variable) and $\mathrm{PO}_{2}$ and C-peptide values (independent variables) in the umbilical artery (UA) and vein (UV) of 98 fetuses with signs suggestive of distress during labor

\begin{tabular}{|c|c|c|c|c|}
\hline & IGFBP-1 & UA & IGFBP-1 & UV \\
\hline & T-value & $P$ level & T-value & $P$ level \\
\hline $\mathrm{PO}_{2}$ & $-2 \cdot 6$ & $0 \cdot 01$ & $-2 \cdot 2$ & 0.03 \\
\hline C-peptide & $-3 \cdot 4$ & $0 \cdot 001$ & $-3 \cdot 5$ & $<0.001$ \\
\hline Intercept & $13 \cdot 5$ & $<0.001$ & $13 \cdot 8$ & $<0 \cdot 001$ \\
\hline $\mathrm{R}^{2}$ of model & $0 \cdot 25$ & $<0.001$ & $0 \cdot 22$ & $<0 \cdot 001$ \\
\hline
\end{tabular}

to hypoxia. The induction of IGFBP-1 gene expression was found to be mediated via hypoxia-inducible-factor-1 (HIF-1). The human IGFBP-1 promoter also contains other regulatory elements, including an insulin response element and glucocorticoid response elements (Powell et al. 1995). Regarding the effect of corticoids, maternal corticoid treatment in rats was reported to induce IUGR and stimulate fetal liver IGFBP-1 gene expression (Price et al. 1992b). Also, UC serum IGFBP-1 concentrations were found to be positively correlated with cortisol levels in 15 human term AGA fetuses (Cianfarani et al. 1998a).

Phosphorylation of IGFBP-1 increases its affinity for IGF-I binding. UV serum contains phosphorylated as well as less- and non-phosphorylated isoforms of IGFBP-1; SGA fetuses were found to have increased levels of phosphorylated, but not non-phosphorylated, IGFBP-1 (Iwashita et al. 1996). Future studies should examine the phosphorylation pattern of IGFBP-1 in the fetal circulation in relation to $\mathrm{PO}_{2}$, insulin and cortisol levels.

The cut-off value for fetal hypoxemia during labor is uncertain. Thorp \& Rushing (1999) reviewed data from 4

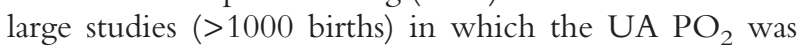
measured: mean values varied between 15.1 and $23.7 \mathrm{~mm}$ $\mathrm{Hg}$, and -1 s.D. values were between 10.2 and $13.7 \mathrm{~mm}$ $\mathrm{Hg}$. The mean $\mathrm{UA} \mathrm{PO}_{2}$ value in this study was $17 \cdot 7 \mathrm{~mm}$ $\mathrm{Hg}$ and the -1 s.D. value was $11.7 \mathrm{~mm} \mathrm{Hg}$. Although this study specifically sampled fetuses with signs suggestive of distress during labor, these clinical signs are known to have poor positive predictive value for fetal hypoxemia; in addition, action was taken to deliver the babies (semi)urgently $(74 \%$ of patients in this series were either instrumentally delivered or underwent an urgent cesarean section). The UA $\mathrm{pH}$ value is clinically the parameter 
most often used to assess in utero oxygenation. In the current study, 25/98 UA samples had a value below 7·20, commonly used in obstetrical practice as a cut-off value for cordocentesis or fetal scalp blood $\mathrm{pH}$ measurements. The [mean - 1 s.D] UA pH value was reported to be between $7 \cdot 11$ and 7.23 in ten large population studies, with values of $7 \cdot 16$ and $7 \cdot 19$ in the largest two studies (Thorp \& Rushing 1999). However, the UA pH value is a measure of both the respiratory and metabolic acid-base status of the fetus. Tazuke et al. (1998) found elevated UA IGFBP-1 levels in fetuses with mixed metabolic/respiratory acidosis, but not in fetuses with respiratory acidosis. In this study, the $\mathrm{pH}$ value, as well as other measures of acid-base status $\left(\mathrm{HCO}_{3}{ }^{-}\right.$and base deficit) were not significant predictors of UA or UV IGFBP-1 levels.

There is consensus that, on average, SGA fetuses have both lower IGF-I levels and higher IGFBP-1 levels in their serum than AGA fetuses. However, IGFBP-1 appears to have better discriminatory power to detect IUGR than IGF-I. Indeed, mean IGF-I levels in cord serum are very low - at least sixfold lower than IGF-I levels in adult sera (Verhaeghe et al. 1993) - and there is a considerable overlap between IGF-I values in AGA and SGA babies. IGFBP-1 levels in cord serum, however, are severalfold higher than in adult sera $(112 \pm 128 \mu \mathrm{g} / \mathrm{l}$ (mean \pm s.D.) in the UA of term fetuses in the current series, compared with $13.6 \pm 9 \cdot 7 \mu \mathrm{g} / 1$ in sera of adult women not taking oral contraceptives (Verhaeghe et al. 1999)); in twins with discordant birth weight, IGFBP-1 levels were markedly higher in the growth-retarded member (Verhaeghe et al. 1996). From these data, it would appear logical to evaluate the potential use of IGFBP-1 as a parameter to predict IUGR: to this end, IGFBP-1 could be measured in amniotic fluid or in maternal serum. We previously found that IGFBP-1 levels in second-trimester amniotic fluid at genetic amniocentesis, although present in high concentrations, cannot predict weight at birth (Verhaeghe et al. 1999). Maternal serum IGFBP-1 levels have been found to be increased at the time of diagnosis by ultrasound of severe IUGR at 22-26 weeks of pregnancy (Fowler et al. 1999). In addition, maternal serum levels of highly phosphorylated IGFBP-1 at 18 weeks of pregnancy were found to correlate negatively with birth weight in 44 women with type 1 diabetes (Gibson et al. 1999). Future studies on the predictive value of maternal serum IGFBP-1 are important and await further investigation.

\section{Acknowledgements}

We thank W Coopmans, M-J Leemput, $\mathrm{R}$ van Bree and E Van Herck for their advice and help, and the doctors and midwives of the Labor Ward for their help with the cord blood sampling.

This study was supported in part by National Institutes of Health Grant HD25220-09 to L C G.

\section{References}

Cianfarani S, Germani D, Rossi L, Argirò G, Boemi S, Lemon M, Holly JMP \& Branca F 1998a IGF-I and IGF-binding protein-1 are related to cortisol in human cord blood. European Journal of Endocrinology 138 524-529.

Cianfarani S, Germani D, Rossi P, Rossi L, Germani A, Ossicini C, Zuppa A, Argirò G, Holly JMP \& Branca F 1998 b Intrauterine growth retardation: evidence for the activation of the insulin-like growth factor (IGF)-related growth-promoting machinery and the presence of a cation-independent IGF bonding protein-3 proteolytic activity by two months of life. Pediatric Research 44 374-380.

Cox GN, McDermott MJ, Merkel E, Stroh CA, Ko SC, Squires CH, Gleason TM \& Russell D 1994 Recombinant human insulin-like growth factor (IGF) binding protein-1 inhibits somatic growth stimulated by IGF-I and growth hormone in hypophysectomized rats. Endocrinology 135 1913-1920.

Crawford RAF, Hills FA, Farkas A \& Chard T 1995 Elevated levels of insulin-like growth factor binding protein-1 in fetal distress. British Journal of Obstetrics and Gynaecology 102 538-540.

Devlieger H, Martens G, Bekaert A \& Eeckels R 2000 Standaarden van geboortegewicht-voor-zwangerschapsduur voor de Vlaamse boreling. Tijdschrift voor Geneeskunde 56 1-14 (in Dutch).

Fowler D, Albaiges G, Lees C, Jones J, Nicolaides K \& Miell J 1999 The role of insulin-like growth factor binding protein-1 phosphoisoforms in pregnancies with impaired placental function identified by Doppler ultrasound. Human Reproduction 14 2881-2885.

Gibson JM, Westwood M, Lauszus FF, Klebe JG, Flyvbjerg A \& White A 1999 Phosphorylated insulin-like growth factor binding protein 1 is increased in pregnant diabetic subjects. Diabetes $\mathbf{4 8}$ 321-326.

Giudice LC, de Zegher F, Gargosky SE, Dsupin BA, de las Fuentes L, Crystal RA, Hintz RL \& Rosenfeld RG 1995 Insulin-like growth factors and their binding proteins in the term and preterm human fetus and neonate with normal and extremes of intrauterine growth. Journal of Clinical Endocrinology and Metabolism $\mathbf{8 0}$ $1548-1555$.

Green LR, Kawagoe Y, Hill DJ, Richardson BS \& Han VKM 2000 The effect of intermittent umbilical cord occlusion on insulin-like growth factors and their binding proteins in preterm and near-term ovine fetuses. Journal of Endocrinology 166 565-577.

Han VKM, Matsell DG, Delhanty PJD, Hill DJ, Shimasaki S \& Nygard K 1996 IGF-binding protein mRNAs in the human fetus: tissue and cellular distribution of developmental expression. Hormone Research 45 160-166.

Iwamoto HS, Murray MA \& Chernausek SD 1992 Effects of acute hypoxemia on insulin-like growth factors and their binding proteins in fetal sheep. American Journal of Physiology 263 E1151-E1156.

Iwashita M, Sakai K, Kudo Y \& Takeda Y 1996 Phosphoisoforms of insulin-like growth factor binding protein-1 in appropriate-for-gestational-age and small-for-gestational-age fetuses. Growth Hormone and IGF Research 8 487-493.

Klauwer D, Blum WF, Hanitsch S, Rascher W, Lee PDK \& Kiess W 1997 IGF-I, IGF-II, free IGF-I and IGFBP-1, -2 and -3 levels in venous cord blood: relationship to birthweight, length and gestational age in healthy newborns. Acta Paediatrica 86 826-833.

Langford K, Blum W, Nicolaides K, Jones J, McGregor A \& Miell J 1994 The pathophysiology of the insulin-like growth factor axis in fetal growth failure: a basis for programming by undernutrition? European Journal of Clinical Investigation 24 851-856.

Lee PDK, Giudice LC, Conover CA \& Powell DR 1997 Insulin-like growth factor binding protein-1: recent findings and new directions. Proceedings of the Society for Experimental Biology and Medicine 216 319-357.

McLellan KC, Hooper SB, Bocking AD, Delhanty PJD, Phillips ID, Hill DJ \& Han VKM 1992 Prolonged hypoxia induced by the reduction of maternal uterine blood flow alters insulin-like growth 
factor-binding protein-1 (IGFBP-1) and IGFBP-2 gene expression in the ovine fetus. Endocrinology 131 1619-1628.

Osborn BH, Fowlkes J, Han VKM \& Freemark M 1992 Nutritional regulation of insulin-like growth factor-binding protein gene expression in the ovine fetus and pregnant ewe. Endocrinology 131 $1743-1750$.

Osorio M, Torres J, Moya F, Pezzullo J, Salafia C, Baxter R, Schwander J \& Fant M 1996 Insulin-like growth factors (IGFs) and IGF binding proteins-1, -2 , and -3 in newborn serum: relationships to fetoplacental growth at term. Early Human Development $\mathbf{4 6}$ $15-26$.

Östlund E, Bang P, Hagenäs L \& Fried G 1997 Insulin-like growth factor I in fetal serum obtained by cordocentesis is correlated with intrauterine growth retardation. Human Reproduction 12 840-844.

Powell DR, Allander SV, Scheimann AO, Wasserman RM, Durham SK \& Suwanichkul A 1995 Multiple proteins bind the insulin response element in the human IGFBP-1 promoter. Progress in Growth Factor Research 6 93-101.

Price WA, Rong L, Stiles AD \& D'Ercole AJ 1992a Changes in IGF-I and -II, IGF binding protein, and IGF receptor transcript abundance after uterine artery ligation. Pediatric Research 32 291-295.

Price WA, Stiles AD, Moats-Staats BM \& D’Ercole AJ $1992 b$ Gene expression of insulin-like growth factors (IGFs), the type 1 IGF receptor, and IGF-binding proteins in dexamethasone-induced fetal growth retardation. Endocrinology 130 1424-1432.

Rajkumar K, Barron D, Lewitt MS \& Murphy LJ 1995 Growth retardation and hyperglycemia in insulin-like growth factor binding protein-1 transgenic mice. Endocrinology 136 4029-4034.

Straus DS, Ooi GT, Orlowski CC \& Rechler MM 1991 Expression of the genes for insulin-like growth factor-I (IGF-I), IGF-II, and IGF-binding proteins- 1 and -2 in fetal rat under conditions of intrauterine growth retardation caused by maternal fasting. Endocrinology 128 518-525.

Tapanainen PJ, Bang P, Wilson K, Unterman TG, Vreman HJ \& Rosenfeld RG 1994 Maternal hypoxia as a model for intrauterine growth retardation: effects on insulin-like growth factors and their binding proteins. Pediatric Research 36 152-158.
Tazuke SI, Mazure NM, Sugawara J, Carland G, Faessen GH, Suen L-F, Irwin JC, Powell DR, Giaccia AJ \& Giudice LC 1998 Hypoxia stimulates insulin-like growth factor binding protein 1 (IGFBP-1) gene expression in HepG2 cells: a possible model for IGFBP-1 expression in fetal hypoxia. PNAS 95 10188-10193.

Thorp JA \& Rushing RS 1999 Umbilical cord blood gas analysis. Obstetric and Gynecology Clinics of North America 26 695-709.

Unterman T, Lascon R, Gotway MB, Oehler D, Gounis A, Simmons RA \& Ogata ES 1990 Circulating levels of insulin-like growth factor binding protein-1 (IGFBP-1) and hepatic mRNA are increased in the small-for-gestational age (SGA) fetal rat. Endocrinology 127 2035-2037.

Verhaeghe J, Van Bree R, Van Herck E, Laureys J, Bouillon R \& Van Assche FA 1993 C-peptide, insulin-like growth factors I and II, and insulin-like growth factor binding protein-1 in umbilical cord serum: correlations with birth weight. American Journal of Obstetrics and Gynecology 169 89-97.

Verhaeghe J, Loos R, Vlietinck R, Van Herck E, van Bree R \& De Schutter A-M 1996 C-peptide, insulin-like growth factors I and II, and insulin-like growth factor binding protein-1 in cord serum of twins: genetic versus environmental regulation. American Journal of Obstetrics and Gynecology 175 1180-1188.

Verhaeghe J, Coopmans W, Van Herck E, Van Schoubroeck D, Deprest JA \& Witters I 1999 IGF-I, IGF-II, IGF binding protein 1, and C-peptide in second trimester amniotic fluid are dependent on gestational age but do not predict weight at birth. Pediatric Research 46 101-108.

Wang HS, Lim J, English J, Irvine L \& Chard T 1991 The concentration of insulin-like growth factor-I and insulin-like growth factor-binding protein-1 in human umbilical cord serum at delivery: relation to fetal weight. Journal of Endocrinology 129 459-464.

Received 7 November 2000

Accepted 30 May 2001 